\title{
INFLUENCE OF THE COLLECTION SEASON ON PRODUCTION, SIZE, AND CHEMICAL COMPOSITION OF BEE POLLEN PRODUCED BY APIS MELLIFERA L.
}

\author{
Adriana F. Negrão ${ }^{1}$ \\ Lidia M. R. C. Barreto² \\ Ricardo 0. Orsi ${ }^{3^{*}}$ \\ 1 Postgraduate Student in Animal Sciences - College of Medicine Veterinary and Animal \\ Sciences - São Paulo University State - UNESP, Botucatu Campus, São Paulo, Brazil \\ 2 Department of Agronomy - University of Taubaté - UNITAU, Taubaté, São Paulo, Brazil \\ ${ }^{3}$ Department of Animal Production - College of Medicine Veterinary and Animal Sciences - \\ São Paulo University State - UNESP, Botucatu Campus, São Paulo, Brazil \\ *corresponding author: orsi@fmvz.unesp.br \\ Received 12 August 2013; accepted 07 November 2014
}

\begin{abstract}
A bstract
The aim of our study was to investigate how the collection period affects and influences the production, chemical composition, and size of bee pollen loads $(0.5,1.0,2.0$, greater than $2.0 \mathrm{~mm}$ ). The results showed there was a predominance of pollen loads with a diameter greater than $2.0 \mathrm{~mm}$ in all the production seasons. For all the seasons, there were no differences in protein content between the particle sizes. But when comparing $0.5 \mathrm{~mm}$ during the different periods, there were significant differences; the highest value was found during the winter $(24.39 \pm 3.7 \%)$. As far as lipids and crude fiber are concerned, we obtained differences between the same granulometry sizes for the spring and summer seasons. As for ashes, the results showed differences between different particle sizes for the summer and autumn seasons. Our results have shown that regardless of pollen particle size, its quality was not altered, suggesting that smaller loads can be commercially used by containing nutritional quality or else be used by beekeepers as a supplement during periods of food scarcity.
\end{abstract}

Keywords: bee pollen, chemical composition, pollen particle size, protein content, seasonal variation.

\section{INTRODUCTION}

The development of a bee colony depends on the quality and quantity of food resources. Pollen is essential for the nourishment and development of the swarm's productive and reproductive potential (Zerbo et al., 2001). Pollen represents the main source of proteins, lipids, vitamins, and minerals. It also plays a key role in the adequate development of the brood, and the nourishment of young bees as well as the functioning of glands and ovaries and the formation of body fat. On the other hand, the chemical composition of bee pollen may vary according to the plant species, environmental conditions, plant age, and nutritional status when the pollen is developing as well as the different locations, seasons and years (Hebert and Shimanuki, 1978; Pernal and Currie, 2000; Szczęsna et al., 2002).
A lack of proteins, carbohydrates, lipids, minerals, and water, may hinder the development, maintenance, and reproduction of the colonies, reduce their life expectancy, cause stress, and propitiate the emergence of diseases. The colony's ability to care for the new brood can also be affected (Brodschneider and Crailsheim, 2010).

The harvesting of pollen from a variety of plant species assures bees a balanced diet (Schimdt and Buchmann, 1993). This suggests a greater foraging effort. However, factors such as pollen-grain size and shape may affect pollen-packing efficiency. Therefore load size, and pollen accessibility may affect the amount of pollen collected for a given foraging effort (Cook et. al., 2003).

Besides, during the bee pollen harvesting, the presence of loads with different sizes have been observed. Often, after classification by sieving 
during the processing, the different sized loads end up having no commercial value and are discarded by the producer. There are no literature data that assess the differences in composition between sizes of these loads. Such differences could present a possible difference in quality.

In this study, we aimed to assess the possible influences that the collection season has on production and chemical composition of bee pollen, and how these parameters relate to the size of the loads $(0.5,1.0,2.0$, and greater than $2.0 \mathrm{~mm})$ collected by bees Apis mellifera L. Our results may provide new information regarding the harvesting frequency and nutritional composition of bee pollen, serving as a tool to start an artificial protein feed to the managed colonies. The feed could be used in times of pollen production scarcity or when pollen quality is insufficient.

\section{MATERIAL AND METHODS}

\section{Bee pollen samples}

The bee pollen samples were produced and collected three times a week from five hives housed at the Lageado Experimental Farm Beekeeping Production Area, UNESP $\left(22^{\circ} 50^{\prime} 30,16^{\prime \prime S} \times 48^{\circ} 25^{\prime} 41,90^{\prime \prime} \mathrm{W}\right)$, located in Botucatu, in the State of São Paulo, Brazil. Between June 2010 and May 2011, Botucatu was characterised by a Cfa climate (a humid subtropical climate with a hot and rainy summer) according to the Köppen climate classification system (Köppen and Geiger, 1928).

The pollen was collected, then immediately frozen to prevent the growth of microorganisms. At the end of each month, the pollen production from the five hives was mixed and dried out in a controlledtemperature oven $\left(40^{\circ} \mathrm{C}\right)$ for $8-12$ hours, until the pollen reached a $4 \%$ moisture content. The pollen was then cleaned to remove impurities, weighed on a thermobalance for the total weight and moisture, and classified using a set of sieves with different sized meshes $(0.5,1.0,2.0$, and greater than $2.0 \mathrm{~mm}$ ). After being assigned to different classes, each month's pollen samples were weighed again, to obtain the granulometry class weight. The pollen samples were frozen $\left(-12^{\circ} \mathrm{C}\right)$ after drying, to preserve the quality until the chemical analysis was performed. Each month, a total of four samples of bee pollen was obtained, one for each classification, totaling forty-eight samples throughout the year.

\section{Chemical analyses}

Total Protein: For establishing the total protein content, $0.7 \mathrm{~g}$ of the samples were digested in a macro Kjeldahl flask containing $4 \mathrm{~g}$ of the catalytic mixture ( $1: 3 \mathrm{CuSO}_{4}$ and $\left.\mathrm{K}_{2} \mathrm{SO}_{4}\right)$ and $20 \mathrm{~mL}$ of concentrated $\mathrm{H}_{2} \mathrm{SO}_{4}$. After digestion, $80 \mathrm{~mL}$ of $40 \% \mathrm{NaOH}$ was added to release ammonia, which was collected in a $\mathrm{H}_{2} \mathrm{SO}_{4}$ solution, and then, titrated with a standardised $\mathrm{NaOH} 0.1 \mathrm{M}$ solution. To determine the total protein, the nitrogen values were multiplied by conversion factor 6.25 (Roulston et al., 2000).

Crude Fiber: For determining the fiber content, $2 \mathrm{~g}$ of milled pollen, defatted in petroleum ether, were heat digested with a solution of $\mathrm{H}_{2} \mathrm{SO}_{4} 0.113 \mathrm{M}$, and subsequently, with a solution of $\mathrm{NaOH} 0.313 \mathrm{M}$, for 30 minutes in each digestion. After neutralising the residue with hot water, washing was performed with $20 \mathrm{~mL}$ of ethanol and $10 \mathrm{~mL}$ of ethyl ether. The residue was then incinerated at $550^{\circ} \mathrm{C}$ in an oven and the fibers quantified by gravimetry (AOAC, 2000).

Lipids: The total lipids were determined by gravimetry. For this, $2 \mathrm{~g}$ of milled pollen were extracted in heat petroleum ether, in a Soxhlet apparatus, during a four-hour period (Almeida-Muradian et. al., 2005).

Ashes: Two grams of previously weighed milled pollen were placed in a porcelain crucible and then incinerated in an oven at $550^{\circ} \mathrm{C}$ until white ash was obtained. After the sample had been cooled in a desiccator, the ashes were determined by gravimetry (Almeida-Muradian et. al., 2005).

\section{Statistical Analysis}

The results were reviewed by One Way ANOVA on Ranks followed by Dunn's test and a t-test for the chemical analysis data, to verify the differences between the means. These were considered statistically different when $p<0.05$ (Zar, 2010).

\section{RESULTS}

Regarding the total production of bee pollen based on the season, we found that the highest average was obtained during the winter (114.67 $\pm 33.1 \mathrm{~g})$, which differed significantly from spring, summer, and autumn (Tab. 1).

There were no differences between the 0.5 and 1.0 granulometric ratings when compared during the same season. Nevertheless, regardless of the 


\section{J. APCL. SCl. VOL. 58 N. 22014}

season, there was a significant predominance of pollen loads with a particle size greater than $2.0 \mathrm{~mm}$ (Tab. 1).

The spring season showed the lowest production for $0.5 \mathrm{~mm}$ granulometry $(0.15 \pm 0.1 \mathrm{~g})$, differing significantly from winter (1.52 $\pm 1.6 \mathrm{~g})$ and autumn $(0.43 \pm 1.9 \mathrm{~g})$. For 1.0 and $2.0 \mathrm{~mm}$ ratings, the highest production was obtained in winter $(1.51 \pm$ $1.2 \mathrm{~g}$ and $9.15 \pm 1.8 \mathrm{~g}$, respectively), differing significantly from other seasons for the same particle size (Tab. 1). As for pollen with a diameter greater than $2.0 \mathrm{~mm}$, we observed a lower amount of bee pollen production for the autumn season (21.61 \pm 17.5 g) (Tab. 1).

As far as $0.5 \mathrm{~mm}$ granulometry was concerned, a lower protein content was observed during the autumn (19.89 $\pm 1.4 \%)$, which differed significantly from winter $(24.39 \pm 3.7 \%)$, but not from summer $(20.79 \pm 1.8 \%)$ or spring $(20.44 \pm 2.4 \%)$. The 1.0 and $2.0 \mathrm{~mm}$ classification showed the highest protein

Bee pollen production according to: seasonality and classification into different meshes

Table 1.

$(0.5,1.0,2.0$, and greater than $2.0 \mathrm{~mm})$ during the spring, summer, autumn, and winter.

The data represent the average followed by the respective standard deviations

\begin{tabular}{|c|c|c|c|c|c|}
\hline \multicolumn{6}{|c|}{ Bee pollen classification (grams and percentage) } \\
\hline & $0.5 \mathrm{~mm}$ & $1.0 \mathrm{~mm}$ & $2.0 \mathrm{~mm}$ & $>2.0 \mathrm{~mm}$ & Total \\
\hline $\begin{array}{c}\text { SPRING } \\
\text { (Sept. Oct. Nov.) }\end{array}$ & $\begin{array}{c}0.15 \pm 0.1 \mathrm{aB} \\
(0.28 \%)\end{array}$ & $\begin{array}{c}0.21 \pm 0.2 \mathrm{aA} \\
(0.39 \%)\end{array}$ & $\begin{array}{c}3.33 \pm 2.9 \mathrm{bA} \\
(6.18 \%)\end{array}$ & $\begin{array}{c}50.16 \pm 17.8 \mathrm{bB} \\
(93.15 \%)\end{array}$ & $53.85 \pm 20.1 A$ \\
\hline $\begin{array}{c}\text { SUMMER } \\
\text { (Dec. Jan. Feb.) }\end{array}$ & $\begin{array}{c}0.29 \pm 0.3 \mathrm{aBC} \\
(0.47 \%)\end{array}$ & $\begin{array}{c}0.26 \pm 0.1 \mathrm{aA} \\
(0.42 \%)\end{array}$ & $\begin{array}{c}2.95 \pm 1.9 \mathrm{bA} \\
(4.81 \%)\end{array}$ & $\begin{array}{c}57.77 \pm 43.5 b B \\
(94.30 \%)\end{array}$ & $61.27 \pm 45.4 \mathrm{~A}$ \\
\hline $\begin{array}{c}\text { AUTUMN } \\
\text { (Mar. April May) }\end{array}$ & $\begin{array}{c}0.43 \pm 1.9 \mathrm{abAC} \\
(1.82 \%)\end{array}$ & $\begin{array}{c}0.25 \pm 0.1 \mathrm{aA} \\
(1.06 \%)\end{array}$ & $\begin{array}{c}1.35 \pm 0.9 \mathrm{bcA} \\
(5.71 \%)\end{array}$ & $\begin{array}{c}21.61 \pm 17.5 \mathrm{cA} \\
(91.41 \%)\end{array}$ & $23.64 \pm 18.5 A$ \\
\hline $\begin{array}{c}\text { WINTER } \\
\text { (June July Aug.) }\end{array}$ & $\begin{array}{c}1.52 \pm 1.6 \mathrm{a} A \\
(1.33 \%)\end{array}$ & $\begin{array}{c}1.51 \pm 1.2 \mathrm{aB} \\
(1.32 \%) \\
\end{array}$ & $\begin{array}{c}9.15 \pm 1.8 \mathrm{abB} \\
(7.98 \%)\end{array}$ & $\begin{array}{c}102.49 \pm 35.3 \mathrm{bB} \\
(89.37 \%) \\
\end{array}$ & $114.67 \pm 33.1 \mathrm{~B}$ \\
\hline
\end{tabular}

The effect of the season in crude protein values - CP (\%), lipids - LP (\%), crude fiber - CF (\%), and ash (\%), from samples of bee pollen (4\% moisture content) collected by Apis mellifera bees during the spring, summer, autumn, and winter seasons. The data represent the average followed by the respective standard deviations

\begin{tabular}{|c|c|c|c|c|c|}
\hline Season & Granulometry & $\begin{array}{c}\text { CP } \\
(\%) \\
\end{array}$ & $\begin{array}{l}\text { LP } \\
(\%)\end{array}$ & $\begin{array}{l}\text { CF } \\
(\%)\end{array}$ & $\begin{array}{l}\text { Ash } \\
(\%)\end{array}$ \\
\hline $\begin{array}{l}\text { SPRING } \\
\text { (Sept. Oct. } \\
\text { Nov.) }\end{array}$ & $\begin{array}{l}\mathrm{mm} \\
\mathrm{mm} \\
\mathrm{mm} \\
0 \mathrm{~mm}\end{array}$ & $\begin{array}{l}20.44 \pm 2.4 a b A \\
21.44 \pm 2.7 \mathrm{abA} \\
21.76 \pm 1.1 \mathrm{abA} \\
20.34 \pm 2.3 \mathrm{aA}\end{array}$ & $\begin{array}{c}-- \\
-- \\
4.95 \pm 2.6 \mathrm{aA} \\
4.30 \pm 2.0 \mathrm{aA}\end{array}$ & $\begin{array}{c}-- \\
-- \\
3.17 \pm 1.4 \mathrm{aA} \\
3.30 \pm 1.8 \mathrm{abA}\end{array}$ & $\begin{array}{c}-- \\
-- \\
2.32 \pm 0.5 \mathrm{aA} \\
2.12 \pm 0.3 \mathrm{aA}\end{array}$ \\
\hline $\begin{array}{l}\text { SUMMER } \\
\text { (Dec. Jan. } \\
\text { Feb.) }\end{array}$ & $\begin{array}{l}0.5 \mathrm{~mm} \\
1.0 \mathrm{~mm} \\
2.0 \mathrm{~mm} \\
>2.0 \mathrm{~mm}\end{array}$ & $\begin{array}{l}20.79 \pm 1.8 \mathrm{abA} \\
20.65 \pm 1.4 \mathrm{abA} \\
21.87 \pm 1.1 \mathrm{abA} \\
20.37 \pm 1.5 \mathrm{aA}\end{array}$ & $\begin{array}{c}-- \\
-- \\
2.28 \pm 0.7 \mathrm{bA} \\
2.28 \pm 0.4 \mathrm{bA}\end{array}$ & $\begin{array}{c}-- \\
-- \\
1.81 \pm 0.3 \mathrm{bA} \\
2.11 \pm 0.5 \mathrm{aA}\end{array}$ & $\begin{array}{c}-- \\
-- \\
2.56 \pm 0.2 \mathrm{aA} \\
2.35 \pm 0.1 \mathrm{aB}\end{array}$ \\
\hline $\begin{array}{l}\text { AUTUMN } \\
\text { (Mar. April } \\
\text { May) }\end{array}$ & $\begin{array}{l}0.5 \mathrm{~mm} \\
1.0 \mathrm{~mm} \\
2.0 \mathrm{~mm} \\
>2.0 \mathrm{~mm}\end{array}$ & $\begin{array}{l}19.89 \pm 1.4 \mathrm{a} A \\
20.21 \pm 1.7 \mathrm{a} A \\
19.63 \pm 1.4 \mathrm{a} A \\
18.66 \pm 1.0 \mathrm{a} A\end{array}$ & $\begin{array}{c}-- \\
-- \\
2.26 \pm 0.4 \mathrm{bA} \\
2.64 \pm 1.0 \mathrm{abA}\end{array}$ & $\begin{array}{c}-- \\
-- \\
2.13 \pm 0.2 \mathrm{abA} \\
2.45 \pm 0.5 \mathrm{aA}\end{array}$ & $\begin{array}{c}-- \\
-- \\
2.74 \pm 0.2 \mathrm{aA} \\
2.41 \pm 0.2 \mathrm{aB}\end{array}$ \\
\hline $\begin{array}{l}\text { WINTER } \\
\text { (June July } \\
\text { Aug.) }\end{array}$ & $\begin{array}{l}0.5 \mathrm{~mm} \\
1.0 \mathrm{~mm} \\
2.0 \mathrm{~mm} \\
>2.0 \mathrm{~mm}\end{array}$ & $\begin{array}{l}24.39 \pm 3.7 \mathrm{bA} \\
23.65 \pm 2.1 \mathrm{bA} \\
22.71 \pm 2.8 \mathrm{bA} \\
20.38 \pm 2.6 \mathrm{aA}\end{array}$ & $\begin{array}{c}-- \\
-- \\
3.43 \pm 0.6 \mathrm{abA} \\
3.65 \pm 0.9 \mathrm{abA}\end{array}$ & $\begin{array}{c}-- \\
-- \\
3.05 \pm 0.8 \mathrm{aA} \\
4.05 \pm 0.8 \mathrm{bB}\end{array}$ & $\begin{array}{c}- \\
-- \\
2.68 \pm 0.3 \mathrm{aA} \\
2.43 \pm 0.2 \mathrm{aA}\end{array}$ \\
\hline
\end{tabular}

Different lowercase letters, for the same granulometry, indicate significant differences between means $(P \leq 0.05)$. Different capital letters for the same season, indicate significant difference between means ( $P \leq 0.05)$. 
content for the winter season $(23.65 \pm 2.1 ; 22.71 \pm$ $2.8 \%$, respectively), which differed from the autumn season $(20.21 \pm 1.7 \%$ and $19.63 \pm 1.4 \%$, respectively). As for a pollen size greater than $2.0 \mathrm{~mm}$, no significant results were found between the different seasons (Tab. 2).

No other analyses were performed for 0.5 and $1.0 \mathrm{~mm}$ granulometries due to insufficient pollen production.

There were differences in the lipid contents between the different seasons for the $2.0 \mathrm{~mm}$ classification. The highest mean was obtained in spring $(4.95 \pm 2.6 \%)$, differing significantly from that of the summer $(2.28 \pm 0.7 \%)$, and autumn $(2.26 \pm 0.4 \%)$ (Tab. 2). The lowest lipid content for pollen loads with a diameter greater than $2.0 \mathrm{~mm}$, was found during the summer $(2.28 \pm 0.4 \%)$, which differed significantly from that found in the spring (4.30 \pm 2.0\%).

For the $2.0 \mathrm{~mm}$ granulometry, the lowest crude fiber content was found in summer $(1.81 \pm 0.3 \%)$. The content was statistically different from spring $(3.17 \pm 1.4 \%)$, and winter $(3.05 \pm 0.8 \%)$. As for the pollen classified in more than $2.0 \mathrm{~mm}$, the highest content was found in winter $(4.05 \pm 0.8 \%)$, which differed from summer and autumn $(2.11 \pm 0.5 ; 2.45$ $\pm 0.5 \%$, respectively) (Tab. 2 ).

As for the ash content, we did not observe significant results between the same granulometry when compared in the different seasons (Tab. 2). However, when comparing different pellet sizes in any one season, we observed statistical differences only for the summer and autumn (Tab. 2).

\section{DISCUSSION}

The highest production, regardless of its granulometric grading, was obtained in the winter. Winter was characterised as a dry season, with low precipitations (ranging from 0.0 to $1.78 \mathrm{~mm}$ ), and a greater insulation period (8.68 \pm 2.0 decimal hours). This data reinforces the hypothesis that bee foraging occurs in periods of low rainfall (Carpes et al., 2009). The reduction in pollen production for the other seasons could be related to the decrease of plants available in the vicinity of the apiary, which limited the floral resource for bees. The low availability of nourishment may also influence the worker bees' foraging activity. A decrease in the size of the colony may then be induced. This can especially be seen in the amount of unsealed brood. A stimulatory effect on pollen collecting is then brought about (Dreller and Tarpy, 2000).
A significant predominance of pollen loads with a granulometry greater than $2.0 \mathrm{~mm}$ was observed in all the studied seasons. According to Roman and Kulik (2006), the size and weight of individual pollen loads collected by bees of the genus Apis may vary from 3.03 to $15 \mathrm{mg}$, depending on the plant which provides food, the colony conditions or needs, and the bee species that makes the harvest. In addition, the percentage of pollen loads which may be gathered from minor fonts and are smaller than $2.0 \mathrm{~mm}$, ranged between 6.8 and $10.6 \%$ in the studied seasons. Sources which were between 1 and 10\% of pollen representation were considered as a secondary resource and had little appeal. However, these pollen types may eventually serve as a complement to the colony dietary needs and become important to maintain its balance, for limited periods, when the resources supply is subject to seasonal variations (Ramalho et al., 1985).

Both the growth and development of bees are mainly influenced by the total protein intake, not only by the amount of nourishment consumed. Moreover, the lack of protein in their diet may reduce immunity in honey bees. Thus, the bees may become more prone to disease, resulting in a significantly lower survival rate (Szymaś and Jędruszuk, 2003). So, it is important to know the quality of the collected bee pollen.

Funari et al. (2003) found higher values for CP (26.2\%) in bee pollen collected in the same region as our study from the previous year. Carpes et. al. (2009) obtained protein levels between 18.55 and $22.60 \%$ in 36 samples from the southern region of Brazil, which are similar to the levels found in our present work.

The autumn season showed lower protein levels when compared with the winter season. There were particle sizes smaller than $2.0 \mathrm{~mm}$, which is probably related to the fact that the pollen composition varies according to the plant species and environmental conditions (Szczęsna et al., 2002). Another possible explanation is that there may have been a reduction in the secondary sources of pollen, used to complement the colony diet. Available food may have become more scarce for these bees, which could possibly have caused a decrease in protein content during the autumn season.

On the other hand, if a protein deficiency is observed, bees may bring pollen loads with a lower granulometry but containing higher protein levels. Once all colony requirements are met, the collecting ceases, reducing productivity. How bees detect the pollen need of a hive, and which signs are used by foragers 
in their evaluation is not yet understood. Camazine (1993) suggested that pollen foragers receive a cue from the nurse bees, in the form of proteinaceous food, which conveys information about their colony's need for pollen. If the protein supply in the hive is high, nurse bees might provide the foragers with this nourishment during trophallaxis, and the foragers will respond to the stimulae.

The lipid content was higher in pellets larger than $2.0 \mathrm{~mm}$, mainly during the spring. Studies show that chemical substances which are attractive to bees, reside in pollen's lipid fraction (Dobson, 1988). In this way, plants presenting pollen with a high concentration of lipid content are more likely to be visited. The lipid results from our present study are similar to those that Oliveira et al. (2009) obtained in 5 samples from southeastern Brazil.

The ash content found in bee pollen was more significant for particles larger than $2.0 \mathrm{~mm}$, during the summer and autumn. The ash content was mostly influenced by floral species and a plant's capacity to accumulate minerals in pollen (Serra Bonvehí et al., 1986). Martins et. al. (2011), obtained ash content ranging between $1.89 \pm 0.29 \mathrm{~g}$ and $3.61 \pm$ $0.32 \mathrm{~g} / 100 \mathrm{~g}$ for bee pollen samples from eleven Brazilian states. This was similar to the results found in our study.

Regarding the crude fiber content, we observed that there were differences only for the winter season when we compare the granulometry of $2.0 \mathrm{~mm}$, and granulometry greater than $2.0 \mathrm{~mm}$. The amount of crude fiber comes from the outer covering of the pollen grain. This covering is basically composed of cellulose and sporopollenin. Funari et. al. (2003) found an average of $1.1 \%$ for crude fiber content in pollen samples in the study area. This was lower than the values that we have obtained.

The Apis mellifera bees have specific nutrient needs for developing their full production and reproductive potential. The amount and composition of pollen may modify the behavior and fecundity of adult bees as well as the life expectancy of workers, the size of brood area, hive population, and quality of larval nourishment (Human et al., 2007).

For these reasons, the frequency of pollen production and knowledge of its chemical composition is worth studying in order to, if necessary, supplement colonies with an artificial source of protein in times of shortage or when the natural pollen presents low protein contents.

\section{CONCLUSIONS}

We can conclude that the collection season influences the pollen composition and its production, as concerns loads greater than $2.0 \mathrm{~mm}$. The results of the present work can contribute information about the pollen quality in a given production area. It may then be possible to add value to this product, which is used for bee nutrition and for animal and human consumption.

\section{ACKNOWLEDGEMENTS}

We are grateful to Luciano Barbosa's expertise and help in reviewing the statistical analysis, and the Fundação de Amparo á Pesquisa do Estado de São Paulo - FAPESP (2010/06074-8) for the scholarship and financial support provided.

\section{REFERENCES}

Almeida-Muradian L. B., Panplona L. C., Coimbra S., Barth O. M. (2005) Chemical composition and botanical evaluation of dried bee pollen pellets. Journal of Food Composition and Analysis 18: 105-1 11.

AOAC. Association of Official Analytical Chemists. (2000) Official methods of analysis of AOAC International. 17th ed. v.2. Association of Analytical Communities. Gaithersburg, MD, USA. 73 pp.

Brodschneider R., Crailsheim K. (2010) Nutrition and health in honey bees. Apidologie 41: 278-294. DOl: 10.1051/apido/2010012

Camazine S. (1993) The regulation of pollen foraging by honey bee: how foragers assess the colony's need for pollen. Behavioral Ecology and Sociobiology 32: 265 272.

Carpes S. T., Cabral I. S. R., Luz C. F. P., Capeletti J. P., Alencar S. M., Masson M. L. (2009) Palynological and physicochemical characterization of Apis mellifera L. bee pollen in the Southern region of Brazil. Journal of Food, Agriculture and Environment 7: 667-673.

Cook S. M., Awmack C. S., Murray D. A., Williams I. H. (2003) Are honey bees' foraging preferences affected by pollen amino acid composition?. Ecological Entomology 28 (5): 622-627. DOl: 10.1046/j.1365-231 1.2003.00548.x 
Dobson H. E. M. (1988) Survey of pollen and pollenkitt lipids-chemical cues to flower visitors. American Journal of Botany 75: 170-182.

Dreller C., Tarpy D. R. (2000) Perception of the pollen need by foragers in a honeybee colony. Animal Behaviour 59: 91-96.

Funari S. R. C., Rocha H. C., Sforcin J. M., Filho H. G., Curi P. R., Gomes Dierckx S. M. S., Funari A. R. M., Orsi R. O. (2003) Composições bromatológica e mineral de pólen coletado por abelhas africanizadas (Apis mellifera L.) em Botucatu, Estado de São Paulo. Archivos Latinoamericanos de Producción Animal 1 1:88-93.

Herbert E. W., Shimanuki H. (1978) Chemical composition and nutritive value of bee-collected and bee-stored pollen. Apidologie 9(1): 33-40.

Human H., Nicolson S. W., Strauss K., Pirk C. W., Dietemann V. (2007) Influence of pollen quality on ovarian development in honeybee workers (Apis mellifera scutellata). Journal of Insect Physiology 53: 649-655. DOl: 10.1016/j.jinsphys.2007.04.002

Köppen W., Geiger R. (1928) Klimate der Erde. Verlag Justus Perthes. Gotha, Germany.

Martins C. T., Morgano M. A., Vicente E., Baggio S. R., Rodriguez-Amaya D. B. (201 1) Physicochemical composition of bee pollen from eleven Brazilian states. Journal of Apicultural Science 55(2): 107-116.

Oliveira K. C. L. S., Moriya M., Azedo R. A. B., Almeida-Muradian L. B., Teixeira E. W., Alves M. L. T. F., Moreti A. C. C. C. (2009) Relationship between botanical origin and antioxidants vitamins of bee-collected pollen. Química Nova 32(5): 1099-1102.

Pernal S. F., Currie R. W. (2000) Pollen quality of fresh and 1 -year-old single pollen diets for worker honey bees (Apis mellifera L.). Apidologie 31: 387-409.
Ramalho M., Imperatriz-Fonseca V. L., Kleinert-Giovannini A., Cortopassi-Laurino M. (1985) Exploitation of floral resources by Plebeia remota (Holmberg) (Apidae, Meliponinae). Apidologie 16: 307-330.

Roman A., Kulik A. (2006). Studies on the relationship between floral fidelity and quantity of pollen hoarded by honeybee (Apis mellifera L.) colonies. Electronic Journal of Polish Agricultural Universities. Animal Husbandry 9 (2). Available at: http://www.ejpau.media.pl/volume9/issue2/ art-22.html

Roulston T. H., Cane J. H., Buchmann S. L. (2000) What

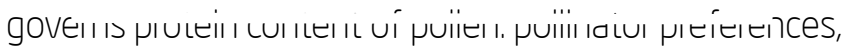
pollen pistil interactions, or phylogeny? Ecological Monographs 70: 617-643.

Schimdt J. O., Buchmann S. L. (1993) Other products of hive. In: Grahan J. M. (Ed.). The hive and the honeybee. Dadant and Sons. Hamilton: 927-988.

Serra Bonvehí J., Gonell Galindo J., Gomez Pajuelo A. (1986) Estúdio de La composición y características físico-quimicas del pólen de abejas. Alimentaria 176: 63-67.

Szczęsna T., Rybak-Chielewska H., Chmielewski W. (2002) Sugar composition of pollen loads harvested at different periods of the beekeeping season. Journal of Apicultural Science 46 (2): 107-115.

Szymaś B., Jędruszuk A. (2003) The influence of different diets on haemocytes of adult worker honey bees, Apis mellifera. Apidologie 34: 97-102.

Zar J. H. (2010) Biostatistical analysis. Pretince Hall. New Jersey, USA. 663 pp.

Zerbo A. C, Moraes R. L. M. S., Brochetto-Braga M. R. (2001) Protein requirements in larvae and adults of Scaptotrigona postiça (Hymenoptera: Apidia, Meliponinae) midgut proteolytic activity and pollen digestion. Comparative Biochemistry and Physiology 129: 139-147. 